\title{
Description of Clean Chip Residual Forest Harvest and Its Availability for Horticultural Uses in the Southeastern United States
}

\author{
Cheryl R. Boyer ${ }^{1,6}$, Thomas V. Gallagher ${ }^{2}$, Charles H. Gilliam ${ }^{3}$, \\ Glenn B. Fain ${ }^{4}$, H. Allen Torbert ${ }^{5}$, and Jeff L. Sibley ${ }^{3}$
}

ADDITIONAL INDEX wORDs. CCR, substrate, alternative media, wood fiber, bark, needles, forestry, nursery, greenhouse

Summary. Residual chipping material, also called clean chip residual (CCR), has potential use as a growth substrate in the nursery and greenhouse horticultural industries. A survey was conducted in the southeastern United States among companies conducting harvesting operations on pine (Pinus sp.) plantations for the production of pulpwood in the forest industry. Fourteen operators in four states (Alabama, Mississippi, Georgia, Florida) were visited to evaluate the on-site status of residual material. Sample analysis of CCR revealed that it was composed of $\approx 37.7 \%$ wood (range, $14.2 \%$ to $50.5 \%$ ), $36.6 \%$ bark (range, $16.1 \%$ to $68.5 \%$ ), $8.8 \%$ needles (range, $0.1 \%$ to $19.2 \%$ ), and $16.9 \%$ indistinguishable (fine) particles (range, $7.5 \%$ to $31 \%)$. $\mathrm{pH}$ ranged from 4.3 to 5.5 for all locations and electrical conductivity (EC) averaged $0.24 \mathrm{mmho} / \mathrm{cm}$. Most nutrients were in acceptable ranges for plant growth with the exception of three sites above recommended levels for iron and four sites for manganese. Survey participants estimated that $\approx 27.5 \%$ of the harvest site biomass was composed of CCR. Some harvesters were able to sell CCR as fuelwood to pulp mills, while others did not recover the residual material and left it on the forest floor (44.3\% total site biomass). Operations in this survey included typical pine plantation chipping and grinding operations (harvesters), woodyards (lumber, fuelwood, etc.), and operations processing mixed material (salvage from trees damaged in hurricanes or mixed tree species cleared from a site that was not under management as a plantation). Residual material varied depending on the plantation age, species composition, site quality, and natural actions such as fire. Average tree age was 11.5 years (range, 8 to 15 years), while average tree stand height was $37.0 \mathrm{ft}$ (range, 25 to $50 \mathrm{ft}$ ) and average diameter at breast height $(\mathrm{DBH})$ was 5.9 inches (range, 4 to 7 inches). Residual material on site was either sold immediately (28.6\%), left on site for 1 to 3 months $(28.6 \%)$, left on site for up to 2 years $(7.1 \%)$, or not collected/sold (35.7\%). Several loggers were interested in making CCR available to horticultural industries. Adequate resources are available to horticultural industries, rendering the use of CCR in ornamental plant production a viable option.

$\mathrm{T}$ here has been a considerable amount of interest in alternative substrates for both nursery and greenhouse crop production in

We thank Jaspreet Aulakh, student worker, for assistance in CCR component data collection. Thanks also to the forest industry cooperators in this project.

Mention of trade names or commercial products in this article is solely for the purpose of providing specific information and does not imply recommendation or endorsement by the U.S. Department of Agriculture.

${ }^{1}$ Assistant Professor, Department of Horticulture, Forestry and Recreation Resources, Kansas State University, Manhattan, KS 66506

${ }^{2}$ Associate Professor, School of Forestry and Wildlife Sciences, Auburn University, Auburn, AL 36849

${ }^{3}$ Professor, Department of Horticulture, Auburn University, Auburn, AL 36849

${ }^{4}$ Assistant Professor, Department of Horticulture, Auburn University, Auburn, AL 36849

${ }^{5}$ Soil Scientist and Research Leader, USDA-ARS National Soil Dynamics Laboratory, Auburn, AL 36832

${ }^{6}$ Corresponding author. E-mail: crboyer@ksu.edu. recent years. This is due primarily to a decrease in domestic production of pine bark (PB), from which the primary substrate in the eastern United States is derived ( $\mathrm{Lu}$ et al., 2006). Another limiting factor has been a change in forest harvesting practices from one that produces $\mathrm{PB}$ as a waste product at the mill to one where $\mathrm{PB}$ is left in the plantation by whole-tree in-field harvesting operations. $\mathrm{PB}$ is a material not readily used by most forest product industries. In fact, it was considered a waste product until the 1950s when alternative uses for $\mathrm{PB}$ were developed (Davidson et al., 2000 ). Today PB is used as a source of fuel, charcoal, wood-based building materials, mulch, soil amendment, and as a container-grown plant substrate (Harkin and Rowe, 1971).

Competition for $\mathrm{PB}$ coupled with a decrease in collection of residual $\mathrm{PB}$ has led to a steady decline in the availability of $\mathrm{PB}$ for horticultural uses. A letter to PB customers from D. Phillips (Phillips Bark Processing; Brookhaven, MS) dated Feb. 2010 stated that, due to the U.S. Federal Biomass Crop Assistance program which had driven the price of raw materials up by a substantial margin, there would be a shortage and possible unavailability of $\mathrm{PB}$ for horticultural and landscape uses (D. Phillips, personal communication). Other growers confirmed the statements from their PB suppliers that they would not be able to fill orders in the coming years (D. Marteney, personal communication). Decreased availability has resulted in price increases for $\mathrm{PB}$, which could affect economic profitability of many growers. In fact, Abt et al. (2009) projected continued price increases and decreased inventory for several timber products through 2030 . Current $\mathrm{PB}$ prices (delivered) range from $\$ 12$ to $\$ 25$ per cubic yard depending on the level of handling (raw, screened, aged, or composted) and freight costs for delivery to far-reaching geographic locations (J. Phillips, personal communications). Additionally, though the "PB crisis" of 2004-10 seems to have passed at this time (J. Phillips, personal communication), the fluctuating market necessitates the continued evaluation of alternative nursery crop substrates.

\begin{tabular}{llll}
\hline $\begin{array}{l}\text { Units } \\
\begin{array}{l}\text { To convert U.S. to SI, } \\
\text { multiply by }\end{array}\end{array}$ & U.S. unit & SI unit & $\begin{array}{l}\text { To convert SI to U.S., } \\
\text { multiply by }\end{array}$ \\
\hline 0.3048 & $\mathrm{ft}$ & $\mathrm{m}$ & 3.2808 \\
3.7854 & gal & $\mathrm{L}$ & 0.2642 \\
2.54 & inch(es) & $\mathrm{cm}$ & 0.3937 \\
0.5933 & $\mathrm{lb} / \mathrm{yard}$ & $\mathrm{kg} \cdot \mathrm{m}^{-3}$ & 1.6856 \\
1 & $\mathrm{mmho} / \mathrm{cm}$ & $\mathrm{dS} \cdot \mathrm{m}^{-1}$ & 1 \\
1 & $\mathrm{ppm}$ & $\mathrm{mg} \cdot \mathrm{kg}^{-1}$ & 1 \\
0.9072 & ton $(\mathrm{s})$ & $\mathrm{Mg}$ & 1.1023 \\
0.7646 & yard & $\mathrm{m}^{3}$ & 1.3080 \\
$\left({ }^{\circ} \mathrm{F}-32\right) \div 1.8$ & ${ }^{\circ} \mathrm{F}$ & ${ }^{\circ} \mathrm{C}$ & $\left(1.8 \times{ }^{\circ} \mathrm{C}\right)+32$
\end{tabular}


The history of alternative substrates in horticultural production is extensive (Boyer, 2008; Lu et al., 2006), yet $P B$ remains the primary source of substrate material for nursery crop production in the last 60 years (eastern and central United States). Industry dogma has been that to use unaged (green) PB or PB with wood fragments is detrimental to plant growth, attributed to significant nitrogen $(\mathrm{N})$ immobilization in these materials. Laiche and Nash (1986) reported that plants grew largest when grown in PB compared with wood chips or PB with wood chips. Investigating these types of substrates was not revisited in the United States until 2005 (Wright and Browder, 2005), though several wood-based substrates have been evaluated in Europe (Gruda and Schnitzler, 2001; Muro et al., 2005). Whole pine trees (either with bark, limbs, and needles or with bark only) have been successfully and extensively evaluated as stable substrate components in recent years (Fain et al., 2008a, 2008b; Jackson et al., 2008, 2009a, 2009b). In substrates composed of $100 \%$ pine tree substrate (PTS) a higher rate of supplemental $\mathrm{N}\left(\approx 2.4 \mathrm{~kg} \cdot \mathrm{m}^{-3}\right)$ was required for 'Compacta' japanese holly (Ilex crenata) and 'Delaware Valley' azalea (Rhododendron obtusum) to achieve shoot growth in PTS comparable to shoot growth in PB (Jackson et al., 2008). Blends of PTS and peat required less limestone than $100 \%$ PTS to achieve ideal production $\mathrm{pH}$ (Jackson et al., 2009b). Whole pine tree materials can be obtained by harvesting trees in plantation salvage situations or in a nursery-owned plantation harvesting operation. A third wood-based substrate material is CCR (Boyer et al., 2007, 2008a, 2008b, 2009). This material is derived as a byproduct of forest thinning operations and is generally left in the plantation or sold to pulp mills for fuel. CCR has higher bark content than whole PTSs, but it has not yet been determined what that percentage is and how it can affect plant growth.

Pine plantation management is an important industry in the southeastern United States, the primary region for loblolly pine [Pinus taeda (Little, 1971)]. Plantations are intensively cultivated to produce large trees resulting in products such as sawtimber, utility poles, and paper
(Wahlenberg, 1960). Plantations are thinned on a regular schedule to make room for the remaining trees to grow larger for the aforementioned wood products. Trees that are harvested in the thinning process are generally used for making paper and as fuel. Clean chips used in the pulping process may contain only $1 \% \mathrm{~PB}$, or the finished paper products will be marred. Residual materials from the harvesting of pine plantations are the limbs, tops, and cull portions of the merchantable and nonmerchantable trees. These residues are woody biomass components not recovered by the harvesting system and are generally sold for fuel or left in the field (Stokes et al., 1989).

CCR has been evaluated as a growth substrate for annuals, perennials, and woody crops. Boyer et al. (2008a) demonstrated that 'Blue Hawaii' ageratum (Ageratum houstonianum) and 'Vista Purple' salvia (Salvia superba) grown in CCR or combinations of CCR and peat produced similar-sized plants when compared with the traditional $\mathrm{PB}$ substrate. Later, Boyer et al. (2008b) evaluated nine perennial species: 'Pink Delight' butterfly bush (Buddleja davidii), 'Siskiyou Pink' gaura (Gaura lindheimeri), 'Early Sunrise' coreopsis (Coreopsis grandiflora), 'Sweet Dreams' coreopsis (Coreopsis rosea), 'Homestead Purple' verbena (Verbena canadensis), 'Butterfly Blue' scabiosa (Scabiosa columbaria), 'Firewitch' dianthus (Dianthus gratianopolitanus), 'Irene' rosemary (Rosemarinus officinalis), and 'Black and Blue' salvia (Salvia guaranitica) in CCR and reported similar results among most substrate blends. Substrates with plants having less growth were primarily the result of substrate physical properties as $100 \%$ CCR had high air space and low water-holding capacity. Addition of peat increased water-holding capacity. All treatments resulted in acceptable growth for perennial species evaluated. A further study indicated that use of supplemental nitrogen was not necessary for growth of 'Pink Delight' butterfly bush (Boyer et al., 2007). Five woody crops such as loropetalum (Loropetalum chinensis var. rubrum), 'Black Knight' butterfly bush (B. davidii), 'Hopi' crapemyrtle (Lagerstroemia indica), 'Natchez' crapemyrtle (Lagerstroemia fauriei), and 'Mrs. G.G. Gerbing' azalea
(Rhododendron indicum) were evaluated for growth in CCR over the course of 1 year (Boyer et al., 2009). Results for woody species were similar to growth responses of annual and perennial crops, but few differences in various growth parameters were also observed. All plants were of acceptable size and quality at the conclusion of the study. CCR has the potential to replace PB and possibly peatmoss as primary nursery and greenhouse crop substrates in several regions of the United States with few changes in crop production strategies as a result of the higher wood content in CCR.

The objectives of this study were to describe the availability, quantity, content, and consistency of substrate materials derived from forest thinning operations. Describing the types of operations from which CCR can be obtained (equipment used, plantation characteristics, etc.) is useful for illustrating to growers what they can expect from a product marketed as "clean chip residual."

\section{Materials and methods}

Fourteen chipping operations (two sites in Hattiesburg, MS were managed by the same operation) were informally surveyed (personal interview) in Summer 2007. Potential survey participants were identified by contacting sales representatives of companies that manufacture forest harvesting equipment (Peterson-Pacific, Eugene, OR and Morbark, Winn, MI), as well as foresters in Alabama, Mississippi, Georgia, and Florida. Most sites were located in a forest plantation setting, but one was a woodyard (primary tree trunks only) and another was a landfill recovery operation.

Survey questions were designed to elicit information about harvesting practices of each operation: 1) what kind of equipment was used (affects the product properties and potential for horticultural use if not ground into small enough particles), 2) how much production was sold or remained in the field (affects the quantity available), and 3 ) information about the stand of trees being harvested (may affect ratios of components, smaller trees have less wood and more green material). Individual loggers were interviewed in person (on site) in an effort to answer the survey questions (Fig. 1). Not all interviewees were able 


\title{
Southeastern U.S. Clean Chip Operation Survey
}

\author{
Site Location: \\ Owner/Operator: \\ Contact Information: \\ 1. What machines do you use? (Model \& Manufacturer, type) \\ a. Chipper \\ b. Grinder \\ 2. What size screens are on the grinder right now? \\ 3. Have you ever used a different screen size? If so, why did you switch and how did it \\ affect your productivity? \\ 4. How much of your CCR is left in the woods? \\ $\%$ \\ 5. How much of your $\mathrm{CCR}$ is processed for the mill to use as fuel? \\ 6. What is your average volume generated? \\ 7. Is your CCR sold or otherwise used for any other purpose? \\ 8. Where is your CCR delivered? \\ 9. What is the average selling price or gatewood fuel price? \\ 10. Would you be willing to change screens on your machine occasionally if horticultural \\ producers would pay more for residual material than you are currently receiving? \\ STAND DATA: \\ 11. Height of stand: \\ 12. Age of stand: \\ 13. Average DBH (diameter at breast height) of trunks: \\ 14. Any other site information (fertilization, herbicides, etc.)
}

Fig. 1. Forest harvesters were asked questions about their operation to describe the availability, quantity, content, and consistency of residual materials derived from the forest thinning process, clean chip residual (CCR), which can be used as nursery and greenhouse crop substrates.

or willing to answer every question on the survey.

Samples, if available, were obtained by filling two 5 -gal buckets with fresh material (representative of the entire harvest, excluding very large branches) collected by hand from within a 20 -ft radius of the processing equipment. Samples were weighed (volumetric bulk density at site), and the approximate age and height of the stand were recorded (based on operator records and counting tree annual growth rings). Tree stand age was measured by DBH (when available) for 15 trees and confirmed with harvester records of site establishment. Samples were further evaluated by sending subsamples to Brookside Laboratories (New Knoxville, $\mathrm{OH}$ ) for soil-less media nutrient analysis.
Material was ground and screened before saturated media extracts (distilled water-based) were prepared from the samples. Substrate $\mathrm{pH}, \mathrm{EC}, \mathrm{N}$ [nitrate $\left(\mathrm{NO}_{3}\right)$, ammonium $\left(\mathrm{NH}_{4}\right)$ ], and micro- and macroelements were measured using this water extract. Plant available $\mathrm{NO}_{3}$ and $\mathrm{NH}_{4}$ were determined using flow injection analysis (FIAlab-2500; FIAlab Instruments ${ }^{\circledR}$, Bellevue, WA) and calcium $(\mathrm{Ca})$, magnesium $(\mathrm{Mg})$, phosphorus $(\mathrm{P})$, potassium $(\mathrm{K})$, sodium $(\mathrm{Na})$, sulfur [sulfate $\left(\mathrm{SO}_{4}\right)$ ], boron $(\mathrm{B})$, manganese $(\mathrm{Mn})$, zinc $(\mathrm{Zn})$, iron (Fe), and copper $(\mathrm{Cu})$ were determined by microwave digestion with inductively coupled plasma-emission spectrometry [ICP (6500 ICAP series; Thermo Jarrell Ash, Offenbach, Germany)]. Three subsamples from each location were dried in a $105^{\circ} \mathrm{C}$ forced-air oven for $48 \mathrm{~h}$ before being separated into components (bark, wood, needles, and indistinguishable). Indistinguishable material is defined as particles too fine to determine whether they were bark, wood, or needles. CCR data were analyzed using Waller-Duncan $k$ ratio $t$ tests $(P \leq 0.05)$ of $\mathrm{SAS}^{\circledR}$ (version 9.1; SAS Institute, Cary, NC).

\section{Results and discussion}

Sites and operations varied in this survey (Table 1). Most were traditional chipping operations working to thin loblolly pine plantations (harvesters) and many were willing to expand their market to horticultural industries. Other sites included woodyards (lumber, fuelwood, etc.) and operations processing mixed material (salvage from trees damaged in hurricanes or mixed tree species cleared from a site that was not under management as a plantation). Residual material varied depending on the plantation age, species composition, site quality, and natural actions such as fire or flood (Burns and Honkala, 1990). For example, trees at Jasper, GA were harvested at a relatively young age ( 8 years) and had the greatest needle content of all sites (19.2\%). Conversely, trees at Waycross, GA had been burned in wildfire and though they were 14 years old at harvest, they had just $8.7 \%$ needles. Bark content was also higher at Waycross (68.5\% vs. $31.3 \%$ ) because pulpwood was collected at Waycross and not at Jasper, which was a "clear-cut" site. Average tree age was 11.5 years (range, 8 to 15 years), while average tree stand height was $37.0 \mathrm{ft}$ (range, 25 to $50 \mathrm{ft}$ ) and average $\mathrm{DBH}$ was 5.9 inches (range, 4 to 7 inches). Residual material on site was either sold immediately $(28.6 \%)$, left on site for 1 to 3 months (28.6\%), left on site for up to 2 years $(7.1 \%)$, or not collected/sold (35.7\%).

Overall, the composition of CCR evaluated in this study was $37.7 \%$ wood (range, $14.2 \%$ to $50.5 \%$ ), $36.6 \%$ bark (range, $16.1 \%$ to $68.5 \%$ ), $8.8 \%$ needles (range, $0.1 \%$ to $19.2 \%$ ), and $16.9 \%$ indistinguishable (fine) particles [range, $7.5 \%$ to $31 \%$ (Table 2 )]. Survey participants estimated that $\approx 27.5 \%$ of the harvest site biomass was composed of CCR. Some harvesters were able to sell CCR as fuelwood to pulp mills, while others did not recover the residual material and 


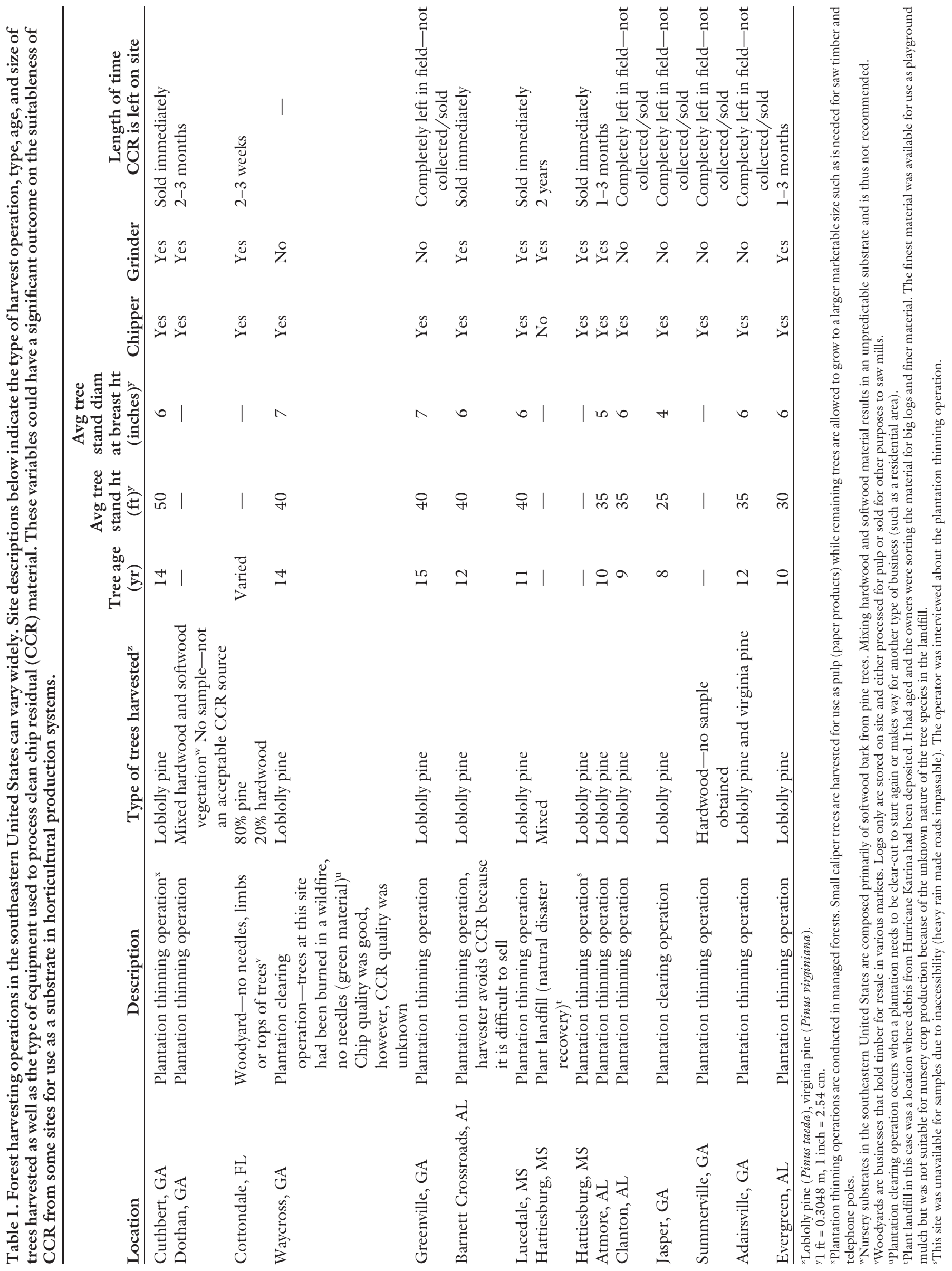


Table 2. Clean chip residual (CCR) obtained from 14 sites had varying amounts of wood, bark, needles, and indistinguishable (fine) material. Distribution of component type and total site biomass of CCR obtained from harvesting locations across the southeastern United States can assist with selection of source material for potential use in nursery and greenhouse crop production.

\begin{tabular}{|c|c|c|c|c|c|c|}
\hline Location & Wood (\%) & Bark (\%) & Needle (\%) & $\begin{array}{c}\text { Indistinguishable } \\
(\%)^{\mathrm{z}}\end{array}$ & $\begin{array}{c}\text { Site biomass composed } \\
\text { of CCR }(\%)^{\mathrm{y}}\end{array}$ & $\begin{array}{c}\text { CCR left } \\
\text { in field }(\%)^{y}\end{array}$ \\
\hline Cuthbert, GA & $44.7 \mathrm{a}^{\mathrm{x}}$ & $35.7 \mathrm{bcd}$ & $12.1 \mathrm{~b}$ & $7.5 \mathrm{a}$ & 25 & 0 \\
\hline Dothan, GA & — $^{\mathrm{w}}$ & - & - & - & - & 0 \\
\hline Cottondale, FL & 38.9 a & $48.8 \mathrm{abc}$ & $0.10 \mathrm{e}$ & $12.2 \mathrm{a}$ & 15 & 0 \\
\hline Waycross, GA & $14.2 \mathrm{a}$ & $68.5 \mathrm{a}$ & $8.7 \mathrm{bcd}$ & $8.7 \mathrm{a}$ & - & 100 \\
\hline Greenville, GA & $31.4 \mathrm{a}$ & $59.7 \mathrm{ab}$ & $0.96 \mathrm{e}$ & $8.0 \mathrm{a}$ & 20 & 100 \\
\hline Hattiesburg, MS & - & - & - & - & 35 & 0 \\
\hline Atmore, AL & $50.4 \mathrm{a}$ & $18.8 \mathrm{~d}$ & $14.2 \mathrm{ab}$ & $16.6 \mathrm{a}$ & 25 & 0 \\
\hline Clanton, AL & - & - & - & - & - & 100 \\
\hline Jasper, GA & $35.4 \mathrm{a}$ & $31.3 \mathrm{~cd}$ & $19.2 \mathrm{a}$ & $14.1 \mathrm{a}$ & 50 & 100 \\
\hline Summerville, GA & - & - & - & - & 20 & 100 \\
\hline Adairsville, GA & $26.5 \mathrm{a}$ & $36.2 \mathrm{bcd}$ & $10.6 \mathrm{bc}$ & $26.7 \mathrm{a}$ & - & 100 \\
\hline
\end{tabular}

${ }^{\mathrm{z}}$ Indistinguishable material was too fine to determine origin (bark, wood, or needles).

${ }^{y}$ Estimate reported by loggers conducting chipping operation at each site.

${ }^{x}$ Means within column followed by the same letter are not significantly different based on Waller-Duncan $\mathrm{k}$ ratio $t$ tests $(\alpha=0.05, n=3)$.

wo sample obtained, interview only.

left it on the forest floor $(44.3 \%$ total site biomass).

Average $\mathrm{pH}$ for the samples ranged from 4.3 to 5.5 , which is near the recommended range of 4.5 to 6.5 for plant growth (Yeager et al., 2007; Table 3 ). EC was below recommended ranges $[0.8$ to $1.5 \mathrm{mmho} / \mathrm{cm}$ (Yeager et al., 2007)] in all samples $(0.16$ to $0.41 \mathrm{mmho} / \mathrm{cm})$. Most nutrients were in acceptable ranges for plant growth with the exception of three sites above recommended ranges for $\mathrm{Fe}$ (recommended range, 0.5 to 2.5 $\mathrm{mmho} / \mathrm{cm}$ ) and four sites for $\mathrm{Mn}$ (recommended range, 0.05 to $2.0 \mathrm{mmho} / \mathrm{cm}$; Table 3 ). One site (Waycross, GA) had Fe levels below $(0.19 \mathrm{mmho} / \mathrm{cm})$ the recommended range. This could be attributed to soil nutrient content at each site; however, these data were not collected.

Appropriate substrate physical properties (air space, water holding capacity, total porosity, and bulk density) of material used for nursery and greenhouse crop production are critical for successful plant growth. Particle sizes of CCR and other alternative substrates can vary greatly depending on the type of equipment used to process them. In the field, chippers are used to coarsely grind pulpwood while a grinder can further process all residual material to a size more suitable for handling and shipping.
Material obtained for the purpose of container-grown crop production would need to be processed a third time in a hammer mill to obtain a variety of particle sizes. Both a grinder and a hammer mill can be fitted with one of several screen sizes. In this survey, $93.3 \%$ of the operations used a chipping machine while only $60 \%$ had a grinder (Table 1). Those operations without a grinder would not be able to process CCR to suitable particle size for horticultural uses. Because of this discrepancy among sites and because material obtained from the equipment on site was not processed to a final production size, data on physical properties at each site was not measured.

Nursery growers usually obtain their substrate material from a distributor, a PB supplier. These businesses purchase PB from a mill or directly from a forest harvester, hold the material in their sales yard (and perhaps conduct some processing such as screening, aging, or composting), and finally deliver directly to growers. $\mathrm{PB}$ suppliers process $\mathrm{PB}$ into many products from "PB nuggets" to "double ground and screened PB." Many suppliers also carry wood chip products for the landscaping market so it is conceivable that they could begin to carry forest residual products to help supply the nursery and greenhouse industries with substrate material. A shift in production practices from $\mathrm{PB}$ to CCR could result in significant savings, steady material price, or both for nursery growers. The fourth quarter 2009 average price for "in-woods whole-tree pine chips" (fuel quality chips, generally from tops, limbs, limited bole material, and otherwise precommercial material) was $\$ 20.96$ per green ton (Timber Mart-South, 2009). In the fourth quarter 2011 , that price had dropped to $\$ 15.50$, and the reported price for "process residuals pine" (includes sawdust, bark, and trimmings) was $\$ 12.02$ (Timber Mart-South, 2012). A thorough economic analysis of the costs associated with bringing CCR to market would include freight (hauling rates and distances, final delivery to a nursery), specialized equipment and time required to operate (grinder, live-bottom trucks), and material handling (screening, composting, or aging). Note that these prices are per green ton rather than cubic yards as the $\mathrm{PB}$ price was reported earlier in this study. Further investigation in the economics of CCR, whole pine trees, PTS, and PB would be beneficial for the adoption of these alternative substrates in the southeastern United States.

The forest product industry produces far more CCR than the horticultural industry can use at this point. 


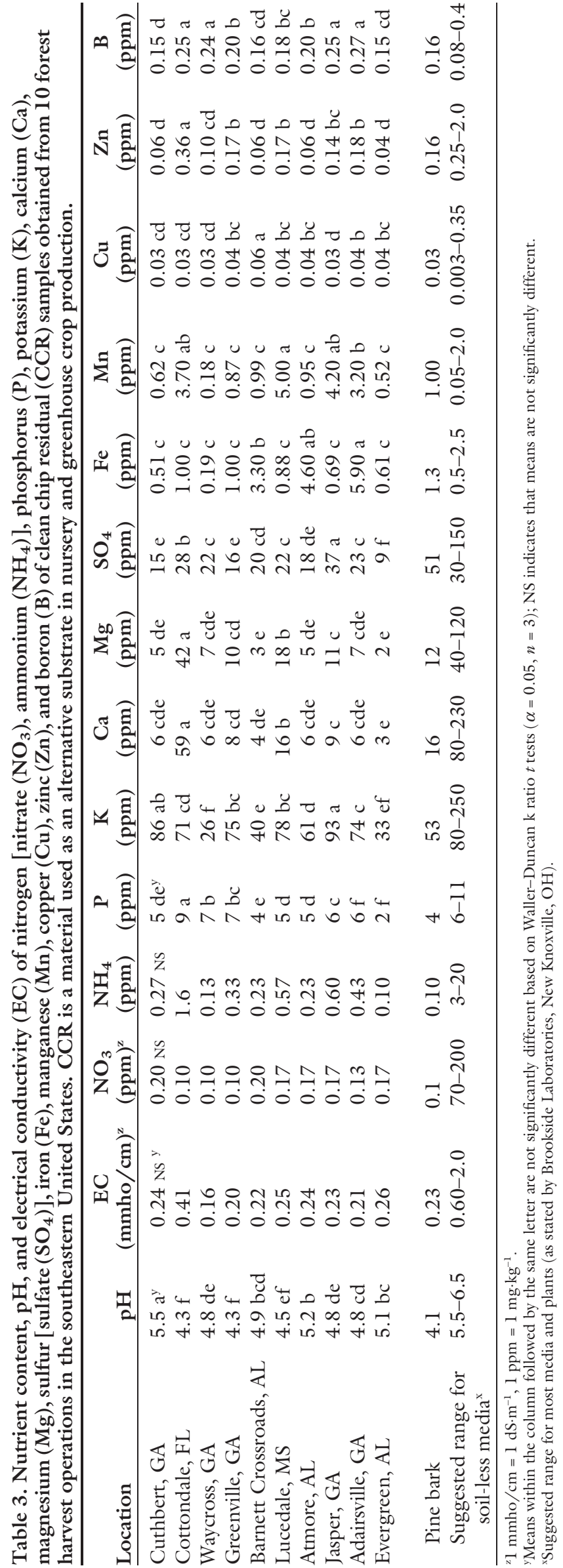

An agreement between loggers and nursery/suppliers as to how much is needed and when it would be needed will be necessary. For example, if the screens on the grinder need to be changed to grind a finer product for horticultural uses and a nursery/ supplier only needs a few truck/van loads, it may be that the logger chooses $1 \mathrm{~d}$ per week or less to harvest for horticultural uses. If a substrate supplier elects to carry CCR (in a similar manner to $\mathrm{PB}$ ), they may want to provide processing (milling, grinding) services as well. Conversely, growers may want to process their own CCR to best meet immediate crop needs. In any case, CCR is a promising alternative substrate component for the horticultural industries. Advantages of using CCR in crop production include fewer input changes (crop growth protocols), local and consistent availability, and long-term sustainability in the southeastern United States. While availability of CCR is adequate, logistics for growers to obtain CCR will need to be determined for future use in horticultural systems.

\section{Literature cited}

Abt, R.C., R.W. Cubbage, and K.L. Abt. 2009. Projecting southern timber supply for multiple products by subregion. For. Prod. J. 59:7-16.

Boyer, C.R. 2008. Evaluation of clean chip residual as an alternative substrate for container-grown plants. Auburn Univ., Auburn, AL, PhD Diss.

Boyer, C.R., G.B. Fain, C.H. Gilliam, T.V. Gallagher, H.A. Torbert, and J.L. Sibley. 2007. Clean chip residual (CCR) substrate for container-grown perennials: Effect of supplemental nitrogen rates. HortScience 42:439. (abstr.).

Boyer, C.R., G.B. Fain, C.H. Gilliam, T.V. Gallagher, H.A. Torbert, and J.L. Sibley. 2008a. Clean chip residual: A substrate component for growing annuals. HortTechnology 18:423-432.

Boyer, C.R., G.B. Fain, C.H. Gilliam, T.V. Gallagher, H.A. Torbert, and J.L. Sibley. 2008b. Clean chip residual as a substrate for perennial nursery crop production. J. Environ. Hort. 26:239-246.

Boyer, C.R., C.H. Gilliam, G.B. Fain, T.V. Gallagher, H.A. Torbert, and J.L. Sibley. 2009. Production of woody nursery crops in clean chip residual substrate. J. Environ. Hort. 27:56-62.

Burns, R.M. and B.H. Honkala. 1990. Silvics of North America: 1. Conifers; 2. 
Hardwoods. U.S. Dept. Agr. For. Serv. Agr. Hdbk. 654.

Davidson, H., R. Mecklenburg, and C. Peterson. 2000. Nursery management: Administration and culture. 4th ed. Prentice Hall, Upper Saddle River, NJ.

Fain, G.B., C.H. Gilliam, J.L. Sibley, and C.R. Boyer. 2008a. WholeTree substrates derived from three species of pine in production of annual vinca. HortTechnology 18:13-17.

Fain, G.B., C.H. Gilliam, J.L. Sibley, C.R. Boyer, and A.L. Witcher. 2008b. WholeTree substrate and fertilizer rate in production of greenhouse-grown petunia (Petunia bybrida Vilm.) and marigold (Tagetes patula L.). HortScience 43:700 705 .

Gruda, N. and W.H. Schnitzler. 2001. Physical properties of wood fiber substrates and their effect on growth of lettuce seedlings (Lactuca sativa L. var. capitata L.). Acta Hort. 548:415-423.

Harkin, J.M. and J.W. Rowe. 1971. Bark and its possible uses. U.S. Dept. Agr. For. Serv. Res. Note 091.

Jackson, B.E., R.D. Wright, J.F. Browder, J.R. Harris, and A.X. Niemiera. 2008. Effect of fertilizer rate on growth of azalea and holly in pine bark and pine tree substrates. HortScience 43:1561-1568.
Jackson, B.E., R.D. Wright, and J.R. Seiler. 2009a. Changes in chemical and physical properties of pine tree substrate and pine bark during long term nursery crop production. HortScience 44:791-799.

Jackson, B.E., R.D. Wright, and N. Gruda. 2009 b. Container medium $\mathrm{pH}$ in a pine tree substrate amended with peatmoss and dolomitic limestone affects plant growth. HortScience 44:1983-1987.

Laiche, A.J., Jr. and V.E. Nash. 1986. Evaluation of pine bark with wood, and pine tree chips as components of a container plant growing media. J. Environ. Hort. 4:22-25.

Little, E.L., Jr. 1971. Atlas of United States trees. Vol. 1. Conifers and important hardwoods. U.S. Dept. Agr. Misc. Publ. 1146.

Lu, W., J.L. Sibley, C.H. Gilliam, J.S. Bannon, and Y. Zhang. 2006. Estimation of U.S. bark generation and implications for horticultural industries. J. Environ. Hort. 24:29-34.

Muro, J., I. Irigoyen, P. Samitier, P. Mazuela, M.C. Salas, J. Soler, and M. Urrestarazu. 2005. Wood fiber as a growing medium in hydroponic crop. Acta Hort. 697:179-185.

Stokes, B.J., D.L. Sirois, and W.F. Watson. 1989. Recovery of forest residues in the southern United States, p. 32-43. In: B.J. Stokes (ed.). Harvesting small trees and forest residues: Proceedings of the 1989 International Energy Agency, task 6, activity 3 symposium. U.S. Dept. Agr. For. Serv., Southern For. Expt. Sta., Auburn, AL.

Timber Mart-South. 2009. 4th quarter 2009 report. Univ. Georgia, Athens. J. Southern Timber Prices 14(4):1-43.

Timber Mart-South. 2012. 4th quarter 2011 supplemental report. Univ. Georgia, Athens.

Wahlenberg, W.G. 1960. Loblolly pine: Its use, ecology, regeneration, protection, growth, and management. Duke Univ., School of Forestry, Durham, NC.

Wright, R.D. and J.F. Browder. 2005. Chipped pine logs: A potential substrate for greenhouse and nursery crops. HortScience 40:1513-1515.

Yeager, T., T. Bilderback, D. Fare, C. Gilliam, J. Lea-Cox, A. Niemiera, J. Ruter, K. Tilt, S. Warren, T. Whitwell, and R. Wright. 2007. Best management practices: Guide for producing nursery crops. 2nd ed. Southern Nursery Assn., Atlanta, GA. 